\title{
ISLAMIC ARCHITECTURAL CHARACTER (BETWEEN LEGITIMACY AND DISPARITY)
}

\author{
Ehab Nasr Elden Ahmed Mohamed
}

\author{
Department of Architectural, Faculty of Engineering, \\ Mataria, Helwan University, Cairo, Egypt \\ e-mail: ehabnasr2000@yahoo.com
}

\begin{abstract}
Despite the cultural background similarity of Arab Islamic architects' seniors and pioneers, and the existence of constants representing legitimacy, the final architectural product varies depending on the individual creativity in relating the architectural elements, either elements that pertain to the identity representation of the inherited architecture or elements pertain to the identity representation of the Arab Islamic contemporary architecture product. That created a specific style for each architect according to the degree of their conclusions, investigation's strategy of traditional roots in their products and works, which are often associated with certain values and the ambit of their interest to represent the identity of contemporary Arab Islamic architecture. In addition to the existence of two main strong motives, the need for affiliation and the need for distinguishing oneself and diversity, in parallel with the presence of the methodological pluralism for every Muslim architect.
\end{abstract}

Keywords: Architectural Character, Islamic Culture, Identity

\begin{abstract}
Abstrak
Terlepas dari kesamaan latar belakang budaya arsitek Islam Arab senior dan perintis, terdapat legitimasi konstan yang mewakili dari variasi produk akhir arsitektur, tergantung pada kreativitas individu dalam hubungannya dengan elemen arsitektur, baik unsur-unsur yang berkaitan dengan representasi identitas warisan arsitektur atau unsur-unsur berkaitan dengan representasi identitas produk arsitektur kontemporer Islam Arab. Hal itu menciptakan gaya tertentu untuk setiap arsitek sesuai dengan tingkat penalaran mereka, strategi investigasi terhadap akar tradisional terhadap produk dan karya mereka, sering dikaitkan dengan nilai-nilai tertentu dan minatnya untuk mewakili identitas kontemporer arsitektur Islam Arab. Selain adanya dua motif utama, kebutuhan afiliasi dan untuk membedakan diri dan keragaman, hal ini seiring pula dengan kehadiran metode pluralitas untuk setiap arsitek Muslim.
\end{abstract}

Kata kunci: Karakter Arsitektur, Budaya Islam, Identitas

\section{Introduction}

Architectural character reflects the society's character identity and features. It results from the cultural pattern, symbols, and social events of the community, in addition to the economic, political, ideological, historical features, prevailing traditions, customs and values of the society.

The success of the architect is measured by the extent of her/his ability in consolidating the relationship between man and space, and the relationship between space and environment. Each architect has her/his own characteristic and individual mark.

When an architect affiliates to a creed, in fact, they develop a distinctive human identity that represents psychological tendency with its own fundamentals and standpoints.

\section{Reasons and justifications of conducting the research}

Given the output of contemporary architecture, the following is observed:

- The absence of architectural and urban identity in many Arab cities for several reasons, most notably the modern architect's lack of awareness and heritage's background scarceness.

- The loss of identity among modern architecture students due to deficiency in architectural courses concerned about the Arab-Islamic identity, nature and character.

- The globalization clear impact on the Arab-Islamic identity.

- The Arab architect's role shrinkage in addressing vital issues suffered by the community.

- The Arab Muslim Architect preoccupation in the search for self-cognitive. 
While observing the Arab Architects pioneers' architecture, the following is concluded:

- The impact of the cultural background and the surrounding environment on them.

- Their awareness of the community's issues, and attempting to resolve and treat them in convenient ways.

- The insight of creativity, social, ideological sides.

\section{Research Methodology}

The research adopts an analytical approach to identify the architectural character; its merits and attributes, the factors affecting its development and structure, and acquires the knowledge of the constants and variables influencing the architectural character's perception. This research studies three leading architects in the Arab region, who possess distinctive and unique architectural character in order to confirm that constants and variables are two important factors in forming the architectural character.

\section{Architectural character}

It is a set of features and distinctive attributes of the architect's personality, or that which describes a particular architecture and is not repeated elsewhere. It is confirmed through the unique techniques belong to an architect in addressing all aspects of architectural design; functional, aesthetic and constructional. Successful architects can fulfill themselves through their works without prejudicing the style ${ }^{1}$. Features refer to all the visual appearances and elements that compose the architectural nature.

The distinctive architectural character challenges the traditionalism ideology, as it deals with the history deeply and interprets it through its own understanding and considering the place in a genuine way rarely replicated elsewhere ${ }^{2}$.

The architectural character is a reason for uniqueness, distinctiveness, individual entity and identity.

\section{Architectural character attributes}

- Creativeness Fluency, which is one of the most important elements of the architectural character, should be held within the architects' personalities so they can innovate in each work produced with reproduction of ideas and diverse alternatives. These renewable additions require a considerable effort for improvement, and architects must deal with different dimensions, circumstances and forms' relationships innovatively, whilst forming the solid and void in mass and space systems to fulfill the psychological, social, artistic and intellectual pleasures. Architect (Sullivan) argues that emotional and transparent characters are qualified and essential to produce inspiring architecture. In his study on innovative architects, (Mackinnon) concluded that the most creative architects are the most productive and intelligent with motivated personalities for accomplishment.

- Expressing Legitimacy, the civilizational yield of the society's heritage, culturally, socially and urban throughout history ${ }^{3}$, is one of the most important responsibilities of modern architects. They should reflect the past as roots, the present as reality and the future as aspiration in their designs, innovations and creations for they represent a figure of their architecture and urban. The past resides amongst us with its architectural, civilizational and cultural heritage, imposes itself in the urban space and acts as a reference that inspires the architects with approaches on how to deal with the environment, climate and techniques alongside with other design parameters. Overall, expression of the community's identity is a necessity in light of global changes.

- Contemporaneity with civilizational commitment in association to the heritage while identifying and studying it. However, continual search for the artistic style which reflects the current era is important and has a role in confirming the architectural character. The search for contemporary architectural figure of which is a form of linking our cultural existence with consecutive history episodes and considers the present as an extension for the past. Exploitation of the technological era with all its capabilities in designs and implementation should be considered.

- Commitment to the society and environment's concerns; every community has its own needs, customs and traditions, in addition to the social and economic circumstances. The architect should grasp it all and abide by it, for the architecture to be a true reflection of the urban environment's components and its conditions and to be compatible with the community's fundamentals of civilization and culture.

- Innovation and imagination, which require intelligence and daring to express their ideas. Architects should possess some important attributes and abilities, such as determining goals, problems solving, research, accuracy and co-operation with the working group. Furthermore, understanding problems, development and testing of hypotheses in a unique style to resolve them.

- The architect should be able to direct and follow the modern management systems; for example project planning, setting evaluation methods and selection of team work. 
Formation of the architectural character

1) Talent, acquired and natural skill besides innate preparedness (blending art with science).

2) Intelligence, creativity and inspiration.

3) Freedom of choosing the vocational orientation.

4) Architectural Education, knowledge, professional awareness and the attitude towards globalization.

5) Socialization.

6) To consider cultural heritage and to have a historical sense and perception of the past for its role in the present.

7) Field visits and spatial privacy.

8) Previous experiences, multiple styles and previous architectural schools, and the gained experiences as it is a tool to associate and recall ideas.

\section{The architect's role and responsibilities}

The title architect, according to the Royal Institute of British Architects ${ }^{4}$, is given to a person with a specialized qualification, who is registered and licensed to practice the profession with the responsible commissioner, holds an architecture degree, and takes responsibility for cultural expression in the society through space, form and historical context. Architects have responsibilities originating from their missive towards the globe's evolution. They have to highlight, preserve and restore the architectural heritage and domestic urban under the globalization currents, and international political conflicts.

Some architects consider expressing the culture and general philosophy prevailing in the society through architecture is the architect's main role. Another responsibility is designing most of the urban environmental components, thus resolves most of the importuning problems while fulfilling the needs, desires and demands of the owners. The architects have to balance between them and his role and duties towards the community.

\section{Factors affecting the formation and growth of the architectural character}

Belief, education, Socialization, cultural heritage and the political system are the most important fundamental factors forming a valuable part of the architect's character. They consolidate her/his identity and affiliation with their formation, composition and growth.

The most important of these factors are:

a) Religious, ideological and social factors

On a national level, the Islamic architecture is the product of local conditions linked with the intellectual foundations of the Islamic belief. On the other side, it is an architecture that sets human production of buildings and urban in harmony with nature's laws and universal codes on a cosmic level. The intellectual and conceptual course was formed through an ideological vision characterized by immutability towards one God. Thus, pace, path, legislation, values and traditions' constancy that yielded an intellectual and physical productions influenced by that vision. Islamic creed was the main steer of the emerged architecture contents of those Islamic eras, which reflected on its external forms; a clear reflection of the ideological, cultural, economic and social community elements.

Islamic architecture varies in its details from one place or period to another (Figure 1), and it is integrated by the unity of religion and belief. Building's craft was developed, responded to users' requirements, achieved their living desires whilst technology compliance to building's science has appeared, which faced with its components the climatic and environmental conditions that vary according to time and place. Islamic architecture eras have become a reference for innovation and mimicry.

Though Western architecture is often prevailed the form over the content, but the Islamic architecture is Islamic in its content, and it is shaped according to the surrounding environment. Islamic architecture fulfils internally the values and desires of the individual user, and consistent externally with the values and desires of the community, which tours and cohabits outside. It has emerged rich with its formational and aesthetic features, which depend on the ornamental units and geometric relationships stemming from structural foundations, technical craft and construction materials. Islamic architecture with its ideological content and constructivist formations comprises the Global Architecture Theory ${ }^{3}$.

Architects should be aware that an architectural product has to merge the Islamic ideology, modern technology and social aspects. They should be aware of the architectural product value, delivery of significance and iconic values of the recipient. Linking architecture with community helps in outlining a civilizational architecture's formula, in which legitimacy and contemporaneity are interrelated.

\section{The Architect and Islamic religion}

Muslims of the first generations invented systems to run their cities, till they become an example to be emulated by most of the world's cities. Islamic religion teachings helped in developing those systems. Some of the well-known principles of Islam and associated with this subject; the Muslim has scruples from within regarding God's and human rights, fair treatment when trading, should not trifle with weights and measures and 
should not commit fraud when trading off and alike. There should be neither harm nor malice, one of the important principles adhered to by Muslims, and prioritizing the public interest over the personal one in association with public facilities' issues. Narrowing a public road, for example, in favor of individual benefit of expanding one house, if it harms the public road, is not allowed.

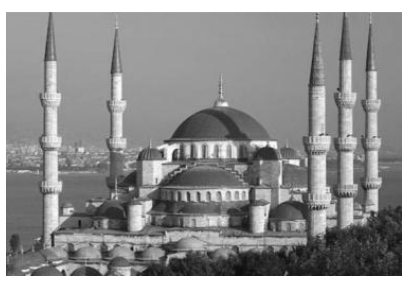

Suleymaniya Mosque, Istanbul, Turkey

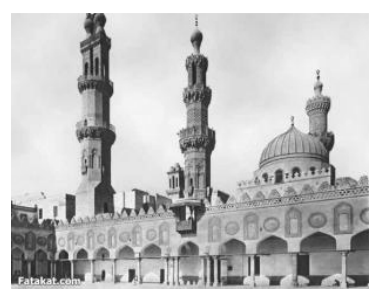

Al-Azhar Mosque, Cairo, Egypt
Figure 1. Islamic architecture details' variations despite of content's constancy.

Islam affirmed in most of its teachings and principles on hygiene, taking into account the neighbor's rights, removal of harmful objects from roads. Islamic sharia permitted taking out a private ownership in favor of public interest benefits. Also preserving the cemeteries, various utilities such as water, trees and the like, besides other lofty principles legislated by Islam to organize people's lives, relationships and homes. Islam was associated with the genesis, emergence and urban of the flourishing Islamic cities renaissance, and its improvement in the organization and urban construction, thus became a model of civilization, progress and development.

Linking architecture to the community helps in outlining a civilizational architectural formula, in which Legitimacy and contemporaneity are interrelated. That is fulfilled by Muslim architects' awareness of that an architectural product has to blend the Islamic ideology, modern technology and social reality, in addition to a sense of the architectural work worth and its delivery of significance and symbolic values to the recipient.

\section{The architect and the society}

As a member of the community, the architect is affected with the current events, which reflects on his work, values and objectives. The patterns and lifestyles of the social environment of Islamic community and its specific connotations influence the architect. Architecture is considered a reflection of the society's conditions, values and ways of thinking. How successful is an architect, is measured by his ability to understand the social needs and circumstances, along with analyzing its member's behavior, and therefore fulfils the society's wishes and aspirations in her/his designs.
A notable example on that is the experiment of Barefoot college staff ${ }^{5}$, established by 'Bunker Roy', which included research programs that introduced amendments into traditional buildings, and injected them with simple and modern techniques easily applied, such as 'Geodesic Domes' invented by ' $R$. Buckminster Fuller'. The college constructed a total of more than two hundred homes in the neighboring villages of (Tilonia), India. Also, a system for collecting rainwater was devised instead of relying on groundwater only; thus it has managed to cultivate new areas. All of the before has upturned the village population and surroundings from an extreme poverty into a better humanitarian life. Noteworthy, the university trained hundreds of professional architects working in many villages (Rajasthan), India ${ }^{8}$.

\section{b) Technological factors}

The domestic building materials and construction technology are considered to be some of the most important architectural forming factors throughout history. The heritage shows how the available technology and suitable materials were employed, along with resolving the constructional problems, such as using arches, domes, muqarnas and the likes to get over wide spans.

An example on that is architect 'Sannan', who constructed many mosques using the technology of building Byzantine churches, as his architecture was influenced by his various military travels around Europe, and especially the Byzantine architecture spread throughout Anatolia.

The technological advancement in the construction field includes developing the constructional systems, methods and materials along with structural means. It is well known that communities extinct if they cannot adapt to the challenges accompanying human evolvement; achieving coexistence and accordance with the ongoing changes becomes the architect's responsibility. By observing the Islamic architecture development, it conceptualizes its own elements according to those eras' technologies. Modern technology enables new capabilities for creativity and innovation while processing the architectural design in terms of vision and modeling, which aided in generating new architectural formations and observing them to rectify potential errors before they are implemented ${ }^{6}$.

\section{c) Political factors}

The architectural remnants from early ages are a strong evidence of politics' influence on architecture and urbanism through history, where they are either representing belief or constructions expressing monarchy and politics endeavoring. In Islamic architecture, Governors had a great impact on directing the policies of constructing mosques, 
castles, walls and palaces. That impact appeared with architects roaming through the Islamic world. Cairo and Morocco were influenced by Iran and Turkey; 'Qoson' mosque minarets in Cairo were designed by architects and builders of (Tabriz), Iran. The same design of the minister (Ali Shah) mosque (Tabriz) was imitated. That example demonstrates the meaning of transferring the properties and architectural values among the Islamic world, and the intellectual continuity within the Islamic content 7 .

Currently, the political factor impact appears, at times expresses the power of governance, reinforcing the authority and protecting the gains, at other times serves to provide the needs of a particular community. At other times, it pushes forward the development wheel for all of the community classes. Political changes, particularly major political transitions, such as revolutions, and the subsequent changes in the economic features along with the society's hierarchy structural changes have a deep impact on the formation of the architect's thoughts and personality. The architect's character is influenced by the surrounding political circumstances whether to adopt the regime's ideology or to be neutral.

By the 1952,'s revolution in Egypt, Egyptian architects were influenced by the Arab nationalism idea, and that Cairo is the Arab and Islamic nation capital, of which has had a significant impact on the architectural and urbanism prosperity. The permanent headquarters of the Arab League is considered one of the most important projects of that period, designed by the Egyptian architect (Mahmoud Riad), 1954. The Architect was keen on endorsing the Islamic identity of Arab cities in this building.

After the $25^{\text {th }}$ of January 2011 revolution, Egyptians Architects cherished a national dream of Egypt's uprising, (i.e. competition of Taking Leave which was adopted by the Center of Sustainability and Future Studies BUE) ${ }^{8}$, British university (Figure 2). Projects like Suez Canal axis and the Path of Development and Reconstruction in Western Sahara by $\mathrm{Dr}$. Farouk El-Baz were introduced.

\section{d) Economic factors}

Over the history of Islam, the architectural art thrives with economic growth and vice versa. A good example is the 'Mamluk' period flourish due to trade routes' booming. For the time being, Economic openness 'Infitah' policy (1980 - 2010) and the economic changes influenced the Egyptian architectural character. Diverse architectural orientations appeared, such as global western, modernity architecture, historical roots and heritage (i.e. Hassan Fathy designs), revivalism (Supreme Constitutional Court in Maadi) as well as the integration between Legitimacy and contemporaneity (American University in New Cairo) orientation.

Regardless the architectural character and identity, the architects' interest turns into achieving the maximum economic returns. In many occasions, they may impose their architectural point of view that conflicts with the user needs.

On a regional level, the Gulf cities represent an architectural flourish due to the discovery of oil and the economic boom in these countries. The City of Abu Dhabi, Doha, Jeddah and Dubai are clear examples of the economic factor impact, as a catalyst, for architectural production.

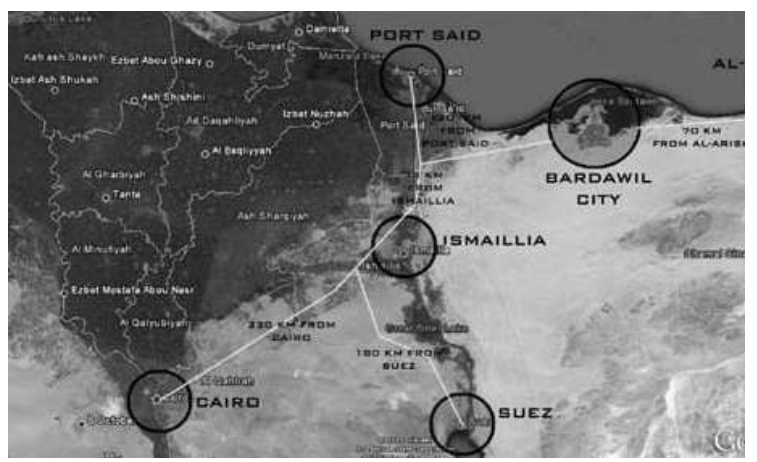

Figure 2. The winning project of the Taking Leave dream award-British university, Egypt.

\section{Cultural factors and the formation of architectural awareness}

The culture represents all that is acquired and not congenital. It is acquired through connecting to other cultures; pre-university education, architectural education, Arts (has its own psychological, social, and ethical impressions), scientific knowledge, schools of thought or new literary, philosophies and theories innovated.

Culture refers to all material and ethical values, beliefs, idols, standards, ideologies and mental explanations collected by humans through their growth and development stages, both socially and historically. It is an indicator and a vision of the artistic, scientific, literature, productive progress level at a particular stage of the society's development.

The Arab references and scientific publications deficiency led to the adoption of the western architecture schools and trends, also supported by a variety and plentiful number of magazines, periodicals and foreign books; the Westernization and cultural invasion matter. The communications revolution and data exchange, on the other hand, have led to cultures overlapping and the knowledge of diverse architectural schools and benefiting from their development ${ }^{6}$. In addition, the enormous development in the software and computer applications has led to cultural identity and 
community needs marginalization while focusing on the shape and formation with no content.

In general, architecture is a culture that can be observed, and in particular, the building expresses a cultural event. Therefore, architects should create a strong relationship with the place and their designs have to be compatible with the cultural context with all its constants and variables. They also have to consider the constructional inheritance and its values where they can be summoned only through a process of "interpretation", which provides a location privacy and distinctive culture to the architectural product. That makes it understandable and desired from both users and recipients, and not through imitation. There are models of distinctive architectural designs that bring in the local heritage values in its formations, but only the heritage values perceived by interpretation.

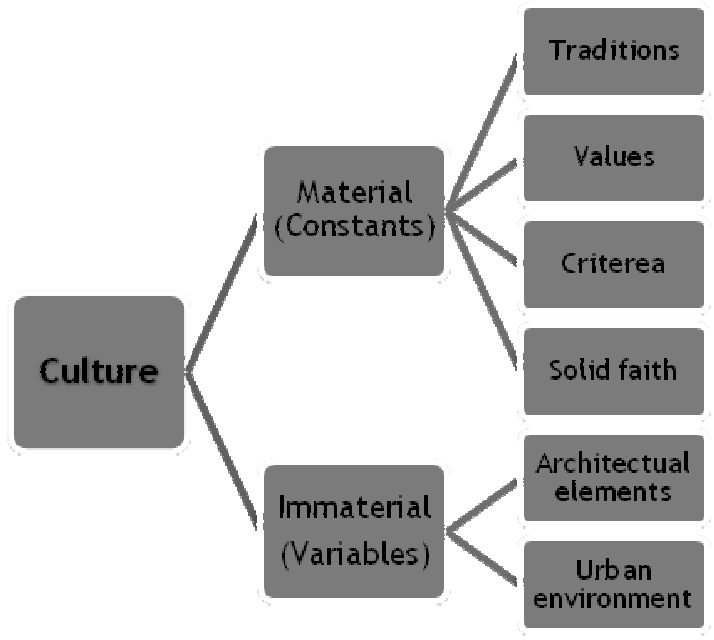

Figure 3. Culture between constants and variables. Source: author

\section{e) Environmental factors}

Environmental factors are a set of natural and generated factors affect the human's health, work, productivity and life in general.

One of the architects' duties is to create a balanced, healthy, safe, comfortable and sustainable urban environment where they utilize convenient means to achieve that. For example, climatic optimums, facades direction, optimum utilization of the nature's energies, such as solar energy and wind.

Respecting the environment evolved within the ethical practices of the Islamic architecture. The environment was considered a source for building materials that incorporates the architectural elements, which is engaged in creating convenient architectural spaces for living aligned with designs' atmosphere that takes into account physical and psychological comfort.

Generally, the Islamic environment is well-known by drought, low rainfall and powerful sun rays' radiation. Early Muslim architects adopted a constructional approach compatible with these climatic facts and took advantage of them. Featuring that, walls were made of stones or bricks with suitable thickness to prevent heat transfer from outside, reducing the openings facing the street as much as possible and directing them towards interior courtyard. Also, they used climate processors such as wind-catcher 'Malqaf' and 'Mashrabiya'.

\section{The architect and the place}

The location has a special significance; it forms the architect's sentiment and inspires familiarity and affiliation into her/his soul. The place is the outcome of the transformations occurring daily due to activities, harmoniousness, interaction and livelihood with the place. The location for the architect represents memories, events and selfexperiences. Each place has its own characteristics stemming from work and life's style. The place has a great impact on thoughts and behavior.

The place is emotionally involved in human's mind through the small details, such as local building materials (stone, brick, wood, etc...) and decorations. Through perceiving the place, we can read and grasp the architect's character (Figure 3), her/his entity and feelings including the affiliation to a particular place and its architectural identity. The understanding of any place's function is by knowing the traditions while the place's comprehension absence causes architectural identity loss.

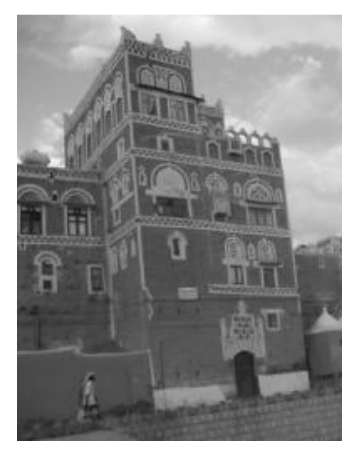

Residential house Sana'a- Yemen

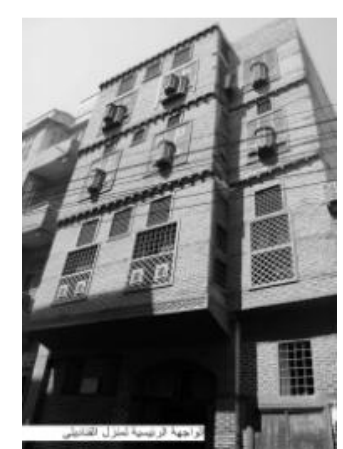

Alguenadely house RashidEgypt
Figure 4. The place influence on the Arab Muslim architect's character.

Architectural character and the constants from an Islamic perspective (Standpoint)

Here are architectural constants (Figure 7):

Constancy of belief and concepts, uniting the vision of existence and life through the one God, the content and thought, architectural identity and affiliation, legitimacy, the place characteristics, the natural environment and climate, abstraction, constants of the material culture represented by the traditions, values and standards. 
The content, from an Islamic perspective, is the functional and ideological aspects' expression in Islamic architecture, so it does not diverge in different locations or periods ${ }^{9}$. In addition, the content is the main engine for the Muslim's architecture designs and thoughts.

The desert's climate and environment requires special processors, such as 'Malqaf', 'Mashrabiya' and adjacent architectural blocks, compact urban tissue, that achieves social cohesion and security.

\section{Architectural character and identity}

Architectural identity is considered an indication of the distinctive architectural character and a description of affiliation to a bigger entity such as society or nation ${ }^{10}$. The architectural heritage, representing the identity and region's nature, is considered as a sensory record and complex visual reference which dates and incorporates for the societies' relationships and their environment. The heritage's consistency and continuity mean that the physical presence of architecture, urbanism and urban content has been elevated through what it shares from attributes, qualities and capabilities. That allows the heritage to respond to the society's needs and reflects their visions to become an effective renewable expression despite its persistence. Heritage for the community means an emphasis on the society's self-nationalism and civilizational.
Cultural Particularism for any nation is based on several axes; some of the most important are its cultural heritage, which includes the artistic heritage of songs, music, folklore, folk drama and popular legends passed through generations after generations.

This inheritance is what saves the nation's identity and distinguishes it from others. It is the result of cultural, social, economic, intellectual, religious, environmental values interactions. Thus, the identity is an attempt to form the Symbolic values; these values create unconscious relationship between the community and architecture products.

The Arab-Islamic city is considered an outcome of human interaction with environmental, cultural and natural factors. With that interaction, the Arab city the architectural and urbanism have been formulated as they represent a distinctive feature of, and so the cultural globalization is attempting to penetrate this fabric and dissolve the human environmental interaction.

Architects attempt, through the architectural identity, to formulate their relationship with the ambience and their memory with the historical and cultural dimension besides the environmental resources, methods, and constructional techniques available.

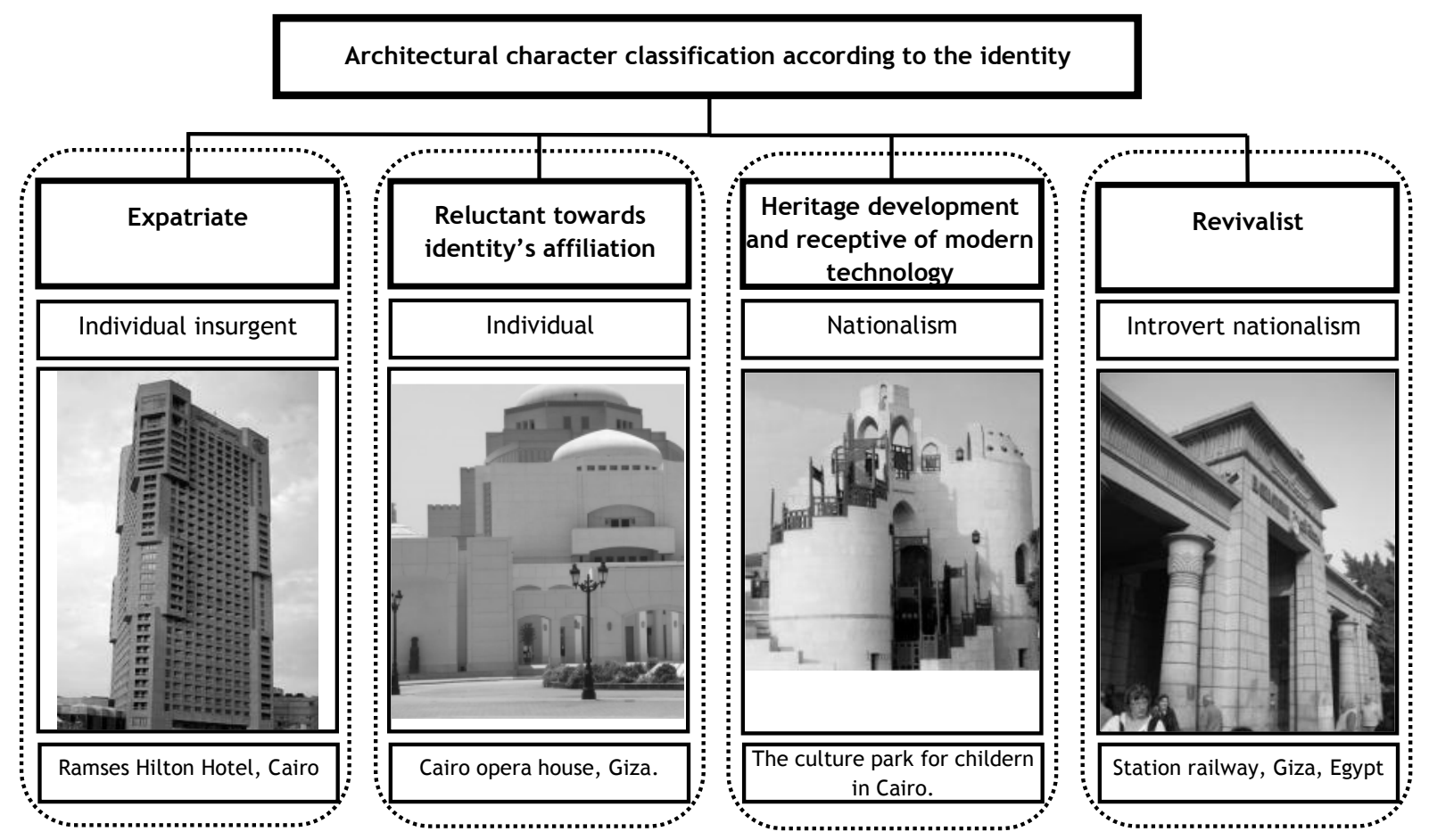

Figure 6. Islamic character classification according to the identity approaching in architectural works. Source: author. 
Classification of architectural character from the identity's viewpoint (Figure 6)

- Revivalist: A non-extrovert character that is fond of nationalism and bigotry toward its ancient heritage, thereby acting on reviving it as it is, without any development or understanding of the content. It ignores the modern technology and its developments which results replication copies of the heritage.

- Heritage development and receptive of modern technology: This character examines, analyzes and apprehends the cultural heritage content, then developing it in accordance to the modern techniques and technology

- Reluctant towards identity's affiliation: This character suffers from the reluctance towards its local identity affiliation for several reasons; most. notably foreign education and fascination with Western civilization, while being raised in an environment that has a nature and a character that they cannot escape from.

- Expatriate: An individual character insurgent upon the past and its replication at modern times due to the lack of proportionality and convenience

\section{Affiliation}

Affiliation is the emotion of belonging to a group or place (includes the means that express certain habits, specific aesthetic icons, self-identity, etc...), which encourages the person's correlation and her/his belonging to the void and the place to be designed, while considering the psychological and biological circumstances which assist in generating different memories and experiences ${ }^{10}$.

This affiliation can be individual, collective, historical or spiritual correlation.

When the architectural and urban void is interrelated to the societies with a specific affiliation, it is of a strong and meaningful sense for them, either local or national and that is increased by satisfying the individuals' different needs which leads to void's affiliation.

The architects' understanding of the society's characteristics and circumstances besides their affiliation to the environment produces a modern architecture that has a very distinctive character.

\section{The architect and environment}

A distinctive architectural character is characterized by a manner that respects the environment by reducing energy consumption, materials and resources while minimizing the constructional and utilization's effects on the environment. It organizes and considers the harmonization and compatibility between the environment, society and the building itself through utilizing local natural materials to build and develop natural inherited climate treatments to suit modernity.
It concentrates while designing projects, on the environmental long-term impact during these projects' operation. In modern times, judging the architectural creativity is not based only on the architectural work aesthetics, but also on its interaction with the surrounding local environment and how it employs a full compatibility, ecologically, with the least of human interaction ${ }^{11}$. The architect should be aware of the surrounding environment's constant and variable conditions, and evolves a link and harmony between the architectural and urbanism work with the surrounding environment.

\section{Administrative systems and regulations}

The architect may consider the issuing licenses' instructions with localities and municipalities, regardless the architectural value that suits the local environment culturally, socially and economically and maybe not setting well with the heritage or the civilizational and cultural environment. Therefore, the skilled architect can design outstanding solutions that balance between national laws, functionality, aesthetics and formations.

\section{Architectural character and disparity}

With the expansion of Islamic countries, more nations and peoples of ancient and classy civilizations joined Islam. Islamic architecture was provided with new data, elements and techniques that contributed through stages of evolution in the development and diversity of architecture styles and arts in Islamic countries technically and aesthetically. Also, innovative expressions and new art elements were introduced, where Muslim architects were inspired by these civilizations and utilized whatever suits the traditions and customs consistent with the Islamic culture. All of that reflected on the Muslim architect character affirmatively and beneficially.

The wealth of building materials provided by a certain location besides evolution of the technological factor and diversity in the developed building materials that followed are some of the most important factors leading to disparity. Other factors worth mentioning are: the various constructional methods and systems, dissimilarity of the architect's deep understanding of the intellectual and physical context of heritage, education and learning, political changes and the impact of new cultures on the community's inherited culture are some of the most important factors of diversity.

Islamic countries cultures diversity had a great role in the enrichment of architecture in these countries. The architectural styles and elements are closely tied to the cultural atmosphere and location, thus change accordingly and vary in shape.

\section{Architectural character determinants:}

Every architect has a distinctive architectural character with its determinants that $s /$ he is convinced with and attempting to apply in her/his design. Noteworthy: 
- Functional determinant: It secures humans existence, survival and their needs such as shelter, protection and comfort. Forming the architectural space to accommodate the various and vital activities is a necessity. It fulfils functional and spatial integration in accordance with spatial convenience and requirements of the appropriate functions of the construction.

\section{- Environmental determinant}

It is fulfilled through composing the formational architectural elements to address climatic conditions such as the sun's orbit, wind's direction, solar radiation ratios, as well as its suitability in addressing the natural and environmental land topography and the site's spatial elements.

\section{- Cultural and symbolic determinant}

It is the relevance of various architectural elements to the user's culture on one side and the cultural reality, on the other hand, in addition to achieving the symbolic requirements which identify and meet the identity, individual and group affiliation requirements besides the symbolic connotations.

\section{- Aesthetic and sensual determinant}

That includes the criteria that aim to clarify the expressional language, such as visual composition, balance, contrast, proportions, rhythm, symmetry and meanings.
As well as achieving humanitarian sensual and cognitive considerations of the architectural product and sensual yield ${ }^{12}$, in addition to the attempt of finding an architectural formula that represents, pleases and achieves the society' needs. That is unlike the Western architectural character, where productions are the result of the architect's thoughts and personality solely.

\section{- Technological determinant}

Utilization and adaptation of the available technology to the utmost is an important feature of the creative architectural character with choosing its optimum compliant the least damaging to the environment

\section{Analytical study}

A number of Arab architects' pioneers were selected, who have been influenced by Islamic architecture, studied its characteristics and interacted with its elements affirmatively. Their curriculum contains distinctive architectural designs that have a unique character or a specific pattern associated with them. They have attempted to highlight the contemporary Islamic civilization characteristics through an urban concept associated with the social, environmental and cultural dimensions, and the relationship balance between man, time and place.

Selected architects are:

- Rasem Badran. Palestinian/Jordanian.

- Abdel Halim Ibrahim. Egypt.

- Mohamed Makiya. Iraq.

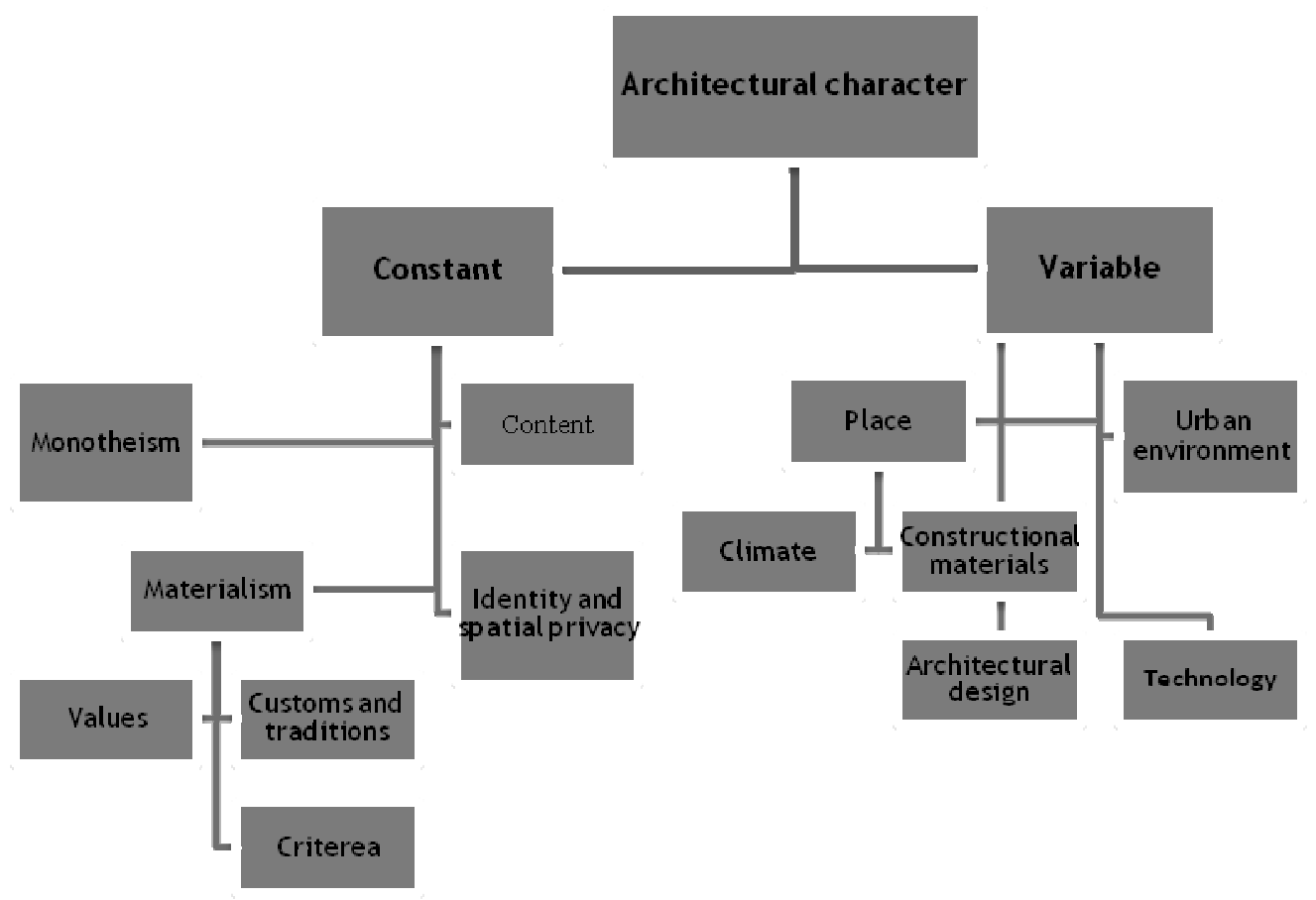

Figure 7. Architectural character between constants and variables. Source: author 
Table 1. Architect 'Rasem Badran' works' analysis

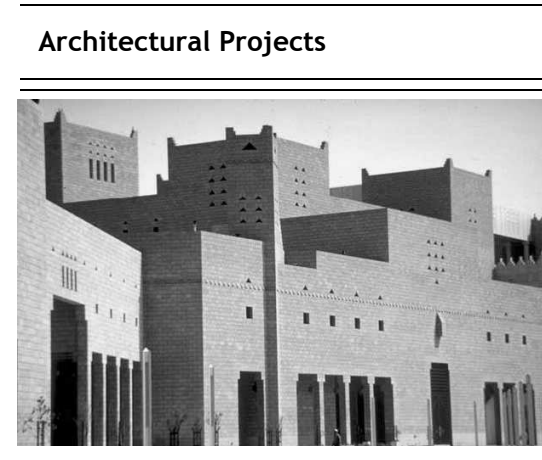

Kasr Al-Hokm, Riyadh, Saudi Arabia.

\section{Architect: Rasem Badran ${ }^{13} \quad$ Country: Palestine/Jordan}

About Born: 1945, winner of Aga Khan Award for
Architecture (AKAA).

Seventies: Respecting local environment and social life's Aspects privacy. Adopted the heritage as a domain for discussing changing and the identity matter.

architecture Eighties: Searching for contemporary architecture with schools' particularism.

influence Nineties: Reintroducing classical architecture in a modern way while being open to the modern architecture.

Architectural Studied architecture and graduated in Germany. education

Influences

His father was a plastic artist, travelling and living in many countries, education in some of the most famous architecture schools, grown up in a country with locational and historical characteristics.

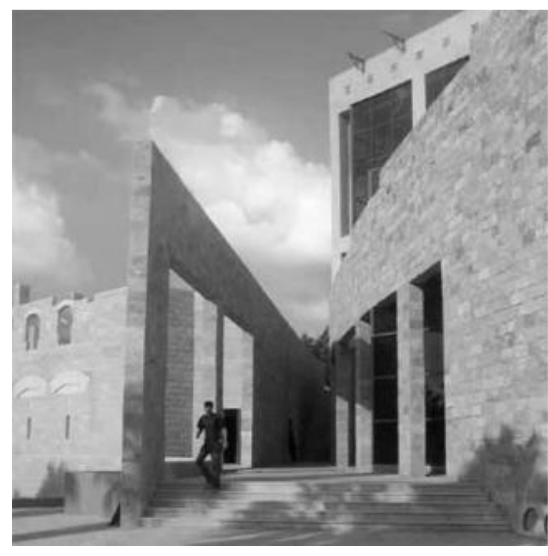

Practice 2 years in Germany after graduation. Established architectural design office in Jordan. Wining local and national competitions.

Affiliation Belongs to the national Islamic
and identity architecture.

Place Growing up in JERUSALEM impacted his architectural character.

\begin{tabular}{lll}
\hline \hline & Ideology & $\begin{array}{l}\text { Clear impact of Islamic faith on his } \\
\text { character. }\end{array}$ \\
\hline \hline \multirow{3}{*}{ Constants } & $\begin{array}{l}\text { Natural } \\
\text { surrounding } \\
\text { environment }\end{array}$ & $\begin{array}{l}\text { Concerned about the harmony between } \\
\text { architecture and geographical content and } \\
\text { habitants' nature. }\end{array}$ \\
\hline
\end{tabular}

Culture Cultural heritage from the father.

Al Yarmouk University- Central LibraryJordan.

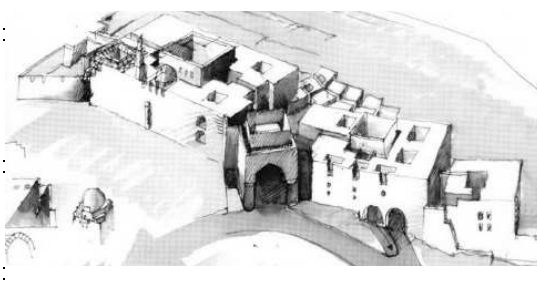

Community
causes

Concerned
contemporaneity with identity, housing causes.

Symbol and Existence of symbols and messages in his meaning works.

Architectural His education in Germany affected his education character. Erudition about modern architecture schools.

Technology Accepting technology additions within his designs.

\begin{tabular}{llll}
\hline \hline & Variabtes & $\begin{array}{l}\text { Construction } \\
\text { materials }\end{array}$ & $\begin{array}{l}\text { Utilized both national and new } \\
\text { constructional materials. }\end{array}$ \\
\cline { 2 - 5 } Al - Beit Foundation - Amman -Jordan & $\begin{array}{l}\text { Architectural } \\
\text { form }\end{array}$ & Aspired by the heritage in a modern way. \\
\hline \hline & $\begin{array}{l}\text { Personal } \\
\text { aspects }\end{array}$ & $\begin{array}{l}\text { Knowledge of the heritage and arising it to } \\
\text { serve the modern and environmental needs. }\end{array}$ \\
\hline \hline & $\begin{array}{l}\text { Architectural } \\
\text { character }\end{array}$ & $\begin{array}{l}\text { Heritage development and receptive for the modern } \\
\text { technology. }\end{array}$ \\
\hline \hline
\end{tabular}

His distinctive architectural character is concerned about the identity cause. Summary Aspired by heritage in a modern way. Succeeded in translating the social, cultural, architectural, environmental and spatial into a visual language of spaces and buildings that have the Arab-Islamic architecture particularism. 
Table 2. Architect 'Abd-ElHalim Ibrahim' works' analysis.

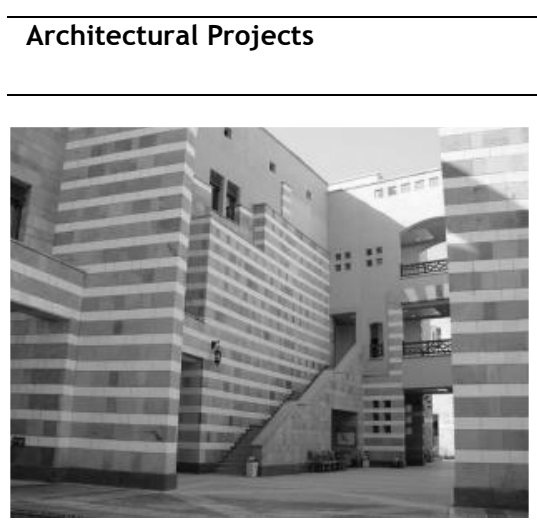
Architect: Abd-ElHalim Ibrahim ${ }^{14 \& 15} \quad$ Country: Egypt

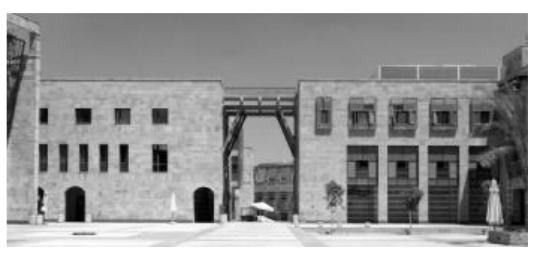

\begin{tabular}{ll} 
About & $\begin{array}{l}\text { Born: 1941, winner of Aga Khan Award for } \\
\text { Architecture (AKAA) for his project of the Children garden } \\
\text { of culture at ElSayda Zaynab 1992. Arab Towns Organization } \\
\text { award and The state award for artistic creation 1993. }\end{array}$ \\
\hline $\begin{array}{l}\text { Aspects } \\
\text { changing }\end{array}$ & $\begin{array}{l}\text { Searching for contemporary architecture with particularism } \\
\text { and Reintroducing classical architecture in a modern way } \\
\text { while being open to the modern architecture. }\end{array}$ \\
\hline Architectural & \begin{tabular}{l} 
Studied architecture in Cairo university and Ph.D. from \\
\hline
\end{tabular}
\end{tabular}

education University of California, Berkeley.

Influences He was raised among artists, Calligraphers and Craftsmen working in the ornamental ceramic factory where his grandfather was a shareholder. The Six-Day War 1967. Inspired by the surrounding environment. Studying abroad. His professor in USA.

$\begin{array}{ll}\text { Academic position after graduation from 'Assiut' university } \\ \text { Practice } & \text { then 'Cairo' university. Design for distinctive buildings; the }\end{array}$
American university is the most recent.

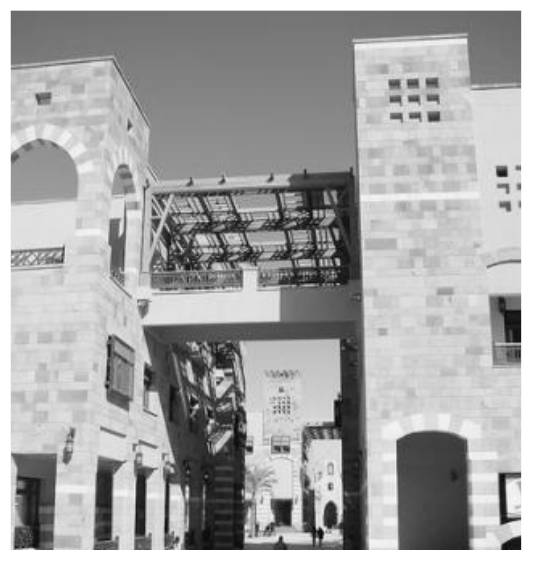

\begin{tabular}{ll} 
Affiliation & $\begin{array}{l}\text { Belongs to the national Islamic } \\
\text { architecture. }\end{array}$ \\
\hline Place & $\begin{array}{l}\text { The location's aspiration has the biggest } \\
\text { influence on his designing philosophy. }\end{array}$ \\
\hline Ideology & $\begin{array}{l}\text { Clear impact of Islamic faith on his } \\
\text { character. }\end{array}$ \\
\hline $\begin{array}{l}\text { surrounding } \\
\text { environment }\end{array}$ & $\begin{array}{l}\text { The built environment in his designs is an } \\
\text { extension of the natural environment. }\end{array}$ \\
\hline
\end{tabular}

\begin{tabular}{|c|c|c|}
\hline Constant & Culture & $\begin{array}{l}\text { Convinced of the culture role and its } \\
\text { importance to achieve development. }\end{array}$ \\
\hline
\end{tabular}

\begin{tabular}{ll} 
Community & $\begin{array}{l}\text { Concerned about with identity, } \\
\text { contemporaneity, legitimism and family } \\
\text { couses }\end{array}$ \\
\hline
\end{tabular}

The American University in Cairo

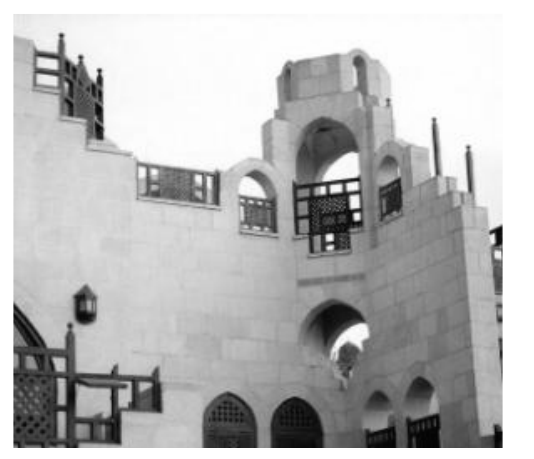

Variables

Symbol and Symbolism and abstraction are considered meaning his most
designs.

Architectural His education in US affected his character education with his erudition about modern architecture schools.

Technology Accepting technology additions within his

\begin{tabular}{lll} 
& designs. \\
\hline Construction & Utilized both national and new
\end{tabular}
materials constructional materials.

Aspired by the heritage in a modern way. Architectural Considering the local architectural form elements, such as hipped roofs, arches and building with bricks or apparent stones. humanity in architecture, such as privacy, Personal humanity, affinity, self-intimacy and human aspects scale. Confirming the relationship between aspects the building, as a social event, and the future, as a reactant, from the design's commencement.

The culture park for childern in Cairo ${ }^{14}$.

\begin{tabular}{ll}
\hline $\begin{array}{l}\text { Architectural } \\
\text { character }\end{array}$ & $\begin{array}{l}\text { Heritage development and receptive for the modern } \\
\text { technology. }\end{array}$
\end{tabular}

His personal distinctive architectural aims to compose an architecture that reflects local reality and carries a simple formational language perceived by the public and professionals alike. A researcher for contemporary architecture. The existence of social participation since the beginning of the design and the need for project's affiliation, for its users to be accepted. 


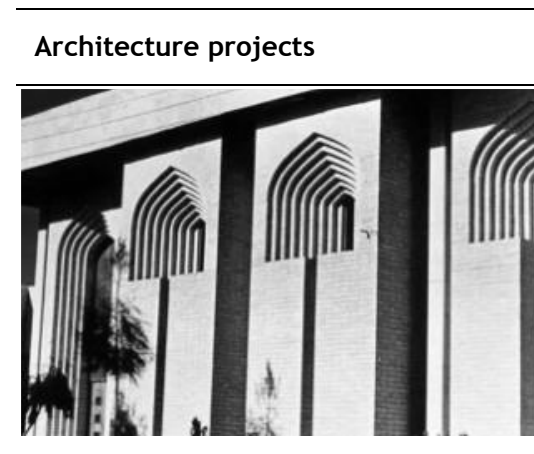

Rafidain Bank, Kufa, Iraq ${ }^{16}$.

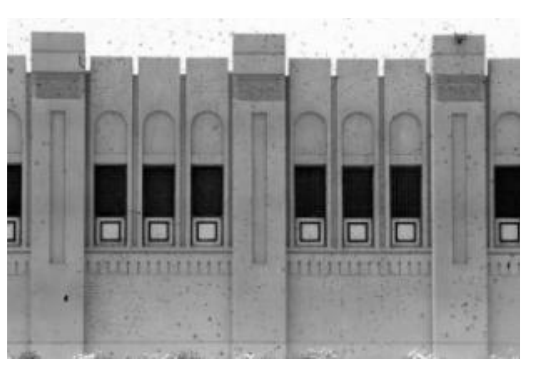

Complex of the Heir Apparent ${ }^{16}$ Rifa'a, Bahrain.

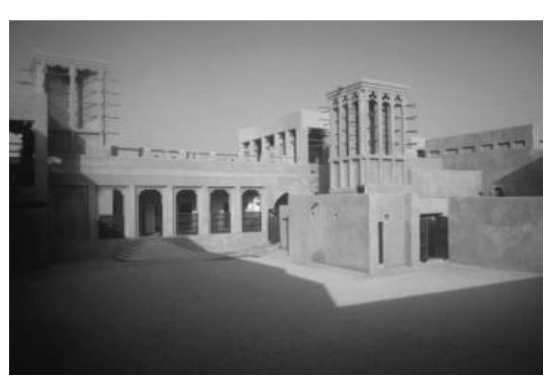

Sheikh Saeed house Restoration Dubai.U.A.E. ${ }^{16}$
Architect: Mohamed Makiya ${ }^{16}$

Country: Iraq

Born: 1914. He established the architecture department in 'Baghdad' university and became its Chief. There is a

About photographed archive for his works at Aga Khan documentation department.

He was considering the heritage as poverty, ignorance and ailment through his study years.

Aspects $\quad$ Forties to Sixties: Followed the traditionalism conservative

changing school and praised both the prevailing constructional elements and materials such as bricks, 'Tabuk'.

Architectural Studied architecture and graduated in England.

education

Born and raised in a popular neighborhood middle of

Influences historical Baghdad. Studied abroad. A conflict between his Islamic background and his study abroad. An educational trip to the British countryside with unique character.

Established 'Makiya partners' office for architecture consultants and design in Baghdad after receiving his Ph.D. He established other branches in many Arab Capitals. Affiliation
and identity Belongs to the national Islamic architecture Affiliation to the place is one of his main

Place undoubted beliefs.

\begin{tabular}{ll}
\hline Ideology & $\begin{array}{l}\text { Clear impact of Islamic faith on his } \\
\text { character. }\end{array}$ \\
\hline $\begin{array}{l}\text { Natural } \\
\text { surrounding } \\
\text { environment }\end{array}$ & $\begin{array}{l}\text { The built environment in his designs is an } \\
\text { extension of the natural environment. }\end{array}$ \\
\hline
\end{tabular}

Constant

Convinced of the culture role and its importance to achieve development.

Community He succeeded in translating the human causes dimension in architecture.

Symbol and The aesthetic and spiritual values contents mymbol and are important the built environment's
context.

Architectural His education in England is on the opposite education side of his thoughts.

Technology Accepting technology additions within his designs.

\begin{tabular}{ll}
\hline $\begin{array}{l}\text { Construction } \\
\text { materials }\end{array}$ & $\begin{array}{l}\text { Utilized both national and new } \\
\text { constructional materials. }\end{array}$ \\
\hline
\end{tabular}

Variables

Aspired by the heritage in a modern way. Architectural Considering the local architectural form elements, such as hipped roofs, arches and building with bricks or apparent stones.

Personal Heritage awareness to revive it in order to serve the time period's and environmental needs.

Architectural Developing architectural character, aspired by the heritage character and an acceptant of technology.

His distinctive architectural character succeeded in translating the human dimension in architecture. Also, he has a great ability of incorporating the inspiring symbols, historical and inherent connotations in contemporary architecture, besides integrating the rich heritage in details and elements with an utmost convenience of the modern technological culture. 


\section{Conclusion}

Architects are associated with function, prospects, requirements, needs, capabilities, technologies and techniques were they should implement technology in consistency with the values, purports, implications and human dimension for each region.

The research has concluded the following:

- Islamic architectural character is the outcome of Islamic civilization and culture ideology elements interaction, derived from the religion and Islamic law (Shari 'a), with local cultures besides the prevailing environmental and climatic conditions. It has benefitted from previous civilizations and developed them in accordance with Islamic religion principles and teachings. It reflects the community's lifestyle and includes customs, traditions, ways of thinking, religious beliefs, moral principles and social values which are some of the main reasons of diversity and variation of Islamic architecture produced in different regions within the same period of time.

- Generally, Arab Muslim architects are absent from the cultural scene. Their work is devoid of any cultural, political connotations, meanings or implications. Most of the architectural designs are not concerned with the social and humanistic dimensions.

- The dissociation of Arab Muslim Architecture's view, due to prevailing western architectural education and schools on one hand, and the actual environmental, social and economic conditions on the other, which represents the same conflict between Classic and modernity or traditionalism and contemporaneity.

- A clear and unique characteristics of Arab Islamic architectural character through Islamic architecture evolution stages which has acquired capabilities and competencies that can keep up with modern developments, and compatible with the technology while adapting it to serve the community's needs in accordance with the social context.

- The constructional heritage values and importance are due to providing the architectural product with a spatial privacy within its own distinctive culture that makes it understandable and accepted by its users and recipients. It is ought to re-interpret the heritage through understanding, observation and analysis, in order to inspire by what is consistent across the interpretation process and for it to be beneficial for architecture and culture.

- Islamic civilization architecture is not limited to a particular form or style, but it is the content or character which is affected by Islamic values. It reinstates psychological balance to Muslim communities to achieve life goals.

- Distinctive architectural character's designs have content, material and symbolic significances that can be observed through understanding and assessing their works. Also, they deal with the place connotations that cannot be replicated elsewhere.

The main cause of urbanism deformation in Islamic countries is the architects' deficient education and upbringing that is due to:

1) Rarity of books discussing the early architectural pioneers' careers, history and production compared to their associates in the west. That led to the western's ideology, content and theories, domination of the architectural library over their local and national counterparts.

2) Omission of addressing the contemporary Islamic civilization architecture and examples of successful projects in the architectural studies of theories and history in architecture academies. It is confined to the inherited architecture's history and the Western's architecture theories.

\section{Recommendations}

To encourage the construction of Muslim architectural character based on the following:

1) The architect adoption of clear architectural orientation that represents Islamic culture and civilization.

2) Correct in depth analysis of the symbols found in the urban environment, which aids in achieving a positive co-habitation with it.

3) An urgent need to review the architecture's theories and history curriculums and materials introduced in architecture academies. They have to be reformulated and provided with aiding frames to contain the authentic architectural character elements. Also, they have to contribute in evolving homogeneity and cohabitation between the architect and the community while linking legitimacy with contemporaneity.

4) Spread awareness, among architecture practitioners and students, of preserving the architectural identity and urban values with its spatial and intellectual dimensions, in addition to civilizational and reputable cultural affiliation importance.

5) The Muslim architect should absorb the heritage's values and their impact on the formation of spatial identity and character without reproducing inconsistence designs with modern times. They should analyse, criticize and understand thoroughly the western architectural schools before creating a standpoint to reproduce it again' beside the creative explanation of Muslim's architectural heritage in order to recreate it in a renewable style with a deep understanding of the overlapping relationships between cultures and the surrounding material environment.

6) The existence of an architectural school of thought inspired by the architectural Islamic and Arab heritage that examines and criticizes the values of contemporary architectural schools in order to be accommodated within an intellectual system. 
- Educating the community of the architect's role while elevate the architects' awareness of the society's role in the architectural product formulation. Considering public erudition programs, with the intellectual awareness and cultural guidance for the owners besides participation in the urban environment evaluation.

- Orientation of Building's visual formulation that debates in richness and harmony with the recipient, representing heritage values that have been reintroduced in a contemporary vocabulary and between a contemporary architecture elements compatible with the heritage to be accepted by the community.

\section{References}

1. Khaled Abdel-Moneim Mansy, 1991. Architectural and urbanism character and urbanization control systems in Egypt. Master thesis, Helwan University.

2. Mishari Bin Abdullah Al-Naim, 12 February 2011. Cultural questions about architectural character. Al-Riyadh daily, Al-Yamamah Press Foundation. Issue no. 15573.

3. Abdel-Baki Ibrahim, 1986. Islamic perspective on architectural theory. Planning and Architectural Studies Center, Cairo.

4. RIBA: Royal Institute of British Architects, catalogue of (RIBA), British Architectural Library, www.architecture.com, Last access 04/01/2014.

5. Ismail Serageldin, 2002. Aga Khan Award for Architecture 2001: Architecture for society, heritage and environment. [Online] (Aga Khan Award for Architecture (AKAA) 2001: Community, heritage and environment architecture), http: / /www.weghatnazar.com/article/article _details.asp?id=62\&issue_id=4, Last access 12/03/2014.

6. Aly Raafat, 1996. Traid of Architectural Creativity (Environment and Space). Interconsult Research Center, Al Giza, Egypt.
7. Abdul Rahman Zaki, 1987. Encyclopedia of the city of Cairo in a thousand years. The Anglo Egyptian bookshop, Cairo. PP, 96.

8. Center of Sustainability and Future Studies, (BUE) The British University in Egypt,Taking Leave Dream Competition https: //www.facebook.com/groups/28041787 1979753/, Last access 04/03/2014.

9. Iman Mohammed Eid, 1993. Islamic content in architectural thought, Towards a theory of Islamic architecture. Master Thesis, Monufia university, Egypt.

10. Ehab Nasr Elden Ahamed, May 2012. The problem of Architecture indentity of Campus Building in new Communities. Journal of engineering Sciences, Assuit University, Vol.40, issue No.2, pp.4.

11. Aly Raafat, 2007. Cycles of Conceptual Creativity- Environmental Cycle(Future Architecture), Inter-consult Research Center, Al Giza, Egypt.

12. Rifat Chadirji, 1988. Problematic architecture and structural theorizing. The world of thought, the National Council for Culture, Arts and Literatures, Kuwait. Volume 27, Issue 2. PP 13,18.

13. James Steele, Rasem Badran, 2005. The Architecture of Rasem Badran: Narratives on People and Place. Thames and Hudson.

14. Edited by James steele, 1992. Architecture for a changing world, The Age Khan award for Architecture and acadmy editions.

15. Community Ceremonies article, 18-24 March 1999. Abdel-Halim Ibrahim interviewed by Fayza Hassan, Al ahram Weekly, issue No.421, http: / / weekly.ahram.org.eg/1999/421/profil e.htm, Last accessed 04/03/2014.

16. Architect's archives, Mohamed Makiya collections.

http://archnet.org/collections/123, Last access 12/03/2014. 